\title{
Queering Gender Through Texture: Possession and Decadence in Mário de Sá- Carneiro's A confissão de Lúcio
}

ISRAEL PECHSTEIN

University of Wisconsin-Madison

\begin{abstract}
Departing from Renu Bora's notion of the queerness of textures, this article seeks to understand how locating the queer textures of Mário de SáCarneiro's 1914 novella, A confissão de Lúcio, emphasizes the work's engagement with questions of gender, modernity, and decadence. Sá-Carneiro's take on modernity has been described as decadent partly because of his refusal or failure to resolve issues of artistic representation with respect to modernity. Approaching A confissão through the queerness of tactility offers a unique insight into the peculiar relationship between the novella's narrator-protagonist, Lúcio Vaz, his friend Ricardo de Loureiro, and Ricardo's wife Marta. Through an exploration of Ricardo's framing of relationships in terms of gendered possession, this article examines Sá-Carneiro's ultimately fraught and decadent figuration of modernity.
\end{abstract}

Keywords: Modernism, Portuguese, masculinity, futurity, body

Mário de Sá-Carneiro's 1914 novella, A confissão de Lúcio, engages with issues of connectedness in the modern world; furthermore, the relationships of its protagonist, Lúcio Vaz, demonstrate Sá-Carneiro's interpretation of modernity. Sá-Carneiro was conscious of, or perhaps even cultivated a decadent esthetic connected with his refusal to develop, evolve, or resolve any crisis involving the 
artistic representation of modernity (including the crisis of representation to which Pessoa replies with his heteronyms). ${ }^{1}$ Drawing from Sherry, I interpret SáCarneiro's novella in a way that reinscribes decadence into Portuguese modernism while seeking out the added textures that this reading brings in terms of queerness and gender fluidity. Sá-Carneiro, through his choice of characters and his esthetics, emphasizes different levels of texture, and perhaps unwittingly queers the relationship between Lúcio, Ricardo de Loureiro, and Marta. I argue that this queering occurs in ways that do not revolve around a supposed love triangle or with Marta serving as a proxy for homosexual desire (Arenas). ${ }^{2}$ My reading considers the implications of the textural on gender identity and fluidity-challenging and expanding ideas of masculinity in the novella. Ultimately, I argue that the text calls attention to a fraught, decadent approach to modernity suggested by the positioning of its characters as dependent on an unattainable physical connection to prove the depth of their relations.

Bora provides a theoretically useful tool in relation to the queerness of texture and tactility. He describes texture (with a single $\mathrm{x}$ ) as "the surface resonance or quality of an object or material" (99) - in other words, surface texture such as smoothness, roughness, hairiness, stickiness. He explains texxture (with two xs) as "the stuffness of material structure" (99) — or texture with depth, pressure. Inspired by Werner Heisenberg's model of vision, Bora states that in texture, the observer's gaze transforms the object of interest due to the deflection of light from its surface (99). With texxture, physical pressure's combined violence and intimacy transforms the object one would like to know through an inherently appropriative gesture (99)-appropriative in the sense that what is touched is altered based on the searching act of touch itself. Bora compares

\footnotetext{
${ }^{1}$ Eiras sees the Orpheu generation's modernism in terms of the contradictory intersection of fragmentation, the unified subject, and the desire for unity (299). I agree with Eiras's interpretation of Sá-Carneiro's project, namely that it is not concerned with creating a world (like Pessoa), but with creating an esthetic experience of the world (300). Specifically, Eiras describes A confissão de Lúcio as a novella in which the protagonist-narrator is "incapable of understanding the mysteries he has glimpsed," and what remains is the novella as "proof of his insufficiency" (307). Alternatively, as Lopes writes: "Sá-Carneiro não acompanhou Pessoa [no] múltiplo desdobrar-se" (32); and "Sá-Carneiro não conseguiu, como Pessoa "voar seu outro"” (34). For a discussion of decadence in Pessoa, see Beleza.

2 Jones builds upon Ana Luísa Amaral's Butlerian emphasis on gender and on the feminine, and she highlights the contributions of the novella's two most important female characters: the unnamed American woman and Marta. Ginway goes so far as to view Ricardo and Marta as "a single transgendered being" (50).
} 
texture and sexuality in their mutual fascination with liminal space, and he describes how both alternatively collapse and create boundaries between the self and the other. In a sense, attention to texture and sexuality reveal the unstable boundaries between entities, the porous nature of a seemingly uniform surface, or the separateness or unity of bodies pressed together.

Textures and sexuality, when considered in relation to bodies, both function in terms of (and simultaneously test) liminality in addition to carrying a certain sensual charge. A confissão de Lúcio itself challenges the very border of artist and art while maintaining the importance of the physical body in this process. Esthetically and morally, Sá-Carneiro's protagonist, like the decadent artists referred to by Matei Calinescu, cultivates a "consciousness of [his] own alienation" (Calinescu 162). A confissão de Lúcio's main characters, however, differ from Calinescu's figuration of decadent art and morality as a rejection of humanism and an embracing of antihumanism, what José Ortega y Gassett later refers to as the "dehumanization of art" (Calinescu 162). Lúcio and Ricardo straddle the line between creating and living art-a division that is bound up in the question of the body and its physicality. In A confissão de Lúcio, one sees that for the characters, the physical nature of the body allows for the artistic representation of the modern to be appreciated. At the same time, the novella adds further texture to the meaning of fully "living" art in how it complicates the opposition between the material nature of the body and the perceived immaterial nature of art. The primacy of texture is evident in Lúcio's repeated desire to touch and feel, which only takes on greater proportions when he meets Ricardo de Loureiro and learns of his notion of possession in friendships.

Textures can also help one to delve into the correspondence between a queer reading and a decadent reading of modernity. Both are self-consciously aware of a quality that makes the modern slippery or difficult to grasp. In A confissão de Lúcio, the very physical texture (i.e., depth) finds tension with the more surface texture (i.e., sensation), and it is in the interplay between these textures that it is possible to understand the relation between the protagonist-writers Lúcio Vaz and Ricardo de Loureiro. By ultimately failing to resolve what I describe as their "impossible" friendship, these characters represent the failure to connect the smooth, shiny, bright nature of modernity to the desire to understand, touch, feel and artistically represent that experience. It is just such an attempt to bridge modernity and art that will eventually come to characterize artistic modernism. 
Pessoa may be a success story of this bridging, but Sá-Carneiro is equally interesting for his apparent challenge to a hegemonic, heterosexual, masculinist imperative. As Butler argues, the very division between women and men comes to exist through heterosexuality, and the "heterosexual matrix" itself is crucial in perpetuating the distinction; beyond this, male heterosexuality relies inherently on the exclusion of homosexuality for its very existence (18). And yet, when Butler speaks of hetero and homosexuality as copies or "parodies," with the former privileged as authentic, she draws attention to the potential for subversion of the heterosexual economy (31). A confissão de Lúcio, through queer tactility and possession as understood and enacted by its characters, demonstrates the power of gender fluidity and ambiguity to challenge the need for resolution to the basic questions of artistic modernism. Such a take on A confissão de Lúcio aligns with Sherry's idea that decadence in some way challenges existing conceptions of modernism (3). Furthermore, A confissão de Lúcio brilliantly illustrates in the tactility experienced between its characters Sherry's point that there exists a "fundamental connection between queerness, which has been assigned to decadence as its most vivid interest (its most livid identity), and the denial of futurity" (26).

\section{Surfaces and Light: Gervásio and the American Woman}

The protagonist and narrator of A confissão de Lúcio, Lúcio Vaz, introduces the novella as a confession to a crime he did not commit. The story proper begins with Lúcio in Paris, where instead of studying law as he had intended, he begins a friendship with the artist Gervásio Vila-Nova, who inducts Lúcio into the city's creative circles. Gervásio foreshadows the theme of possession, commenting to Lúcio, "não sou eu nunca que possuo as minhas amantes; elas é que me possuem" (22). Despite the description of Gervásio as in-the-know and defending the most marvelous of opinions, the narrator notes that "tudo se cifrava nessa auréola, que o seu génio - talvez por demasiado luminoso - se consumiria a si próprio, incapaz de se condensar numa obra-dispero, quebrado, ardido. [...] Não um falhado porque teve a coragem de se despedaçar" (23). The observation about Gervásio's outward intelligence but lack of productivity demonstrates a consciousness of the subtleties of a decadent esthetic within the same modernity that, in Lúcio's mind, Gervásio represents. Gervásio is modern on the exterior, 
but Lúcio casts doubt on the depth of Gervásio's commitment to any meaningful artistic engagement with modernity, pointing out that he has always praised the "pseudo-escola literária da última hora" and extols the virtues of books he has never read (25). Rather than seeing Gervásio's inability to produce artwork as discouraging, however, Lúcio considers this deliberate failure to be admirable. Gervásio values only brilliance in artists and cherishes the same in his friendships. His relation to Lúcio remains at the level of texture - a shiny, hard exterior, but one that is impervious to Lúcio's desire to probe the surface or press into the texxture.

The narrative further exposes Lúcio's reticence and simultaneous fascination with respect to textures in his account of the unnamed American woman artist he meets through Gervásio. She was "qualquer coisa de sonhadamente, de misteriosamente belo. Uma criatura alta, magra, de um rosto esguio de pele dourada - e uns cabelos fantásticos, de um ruivo incendiado, alucinante" (24). Her features foreshadow the fantastical mixture of beauty and danger that Lúcio will later associate with Ricardo and Marta. Indeed, the American woman even mentions that she knows Ricardo de Loureiro. Of special interest to the discussion of gender, art, and modernity is the red-haired woman's perspective regarding sensuality in art:

Venham cá, digam-me: fremir em espasmos de aurora, em êxtases de chama, ruivos de ânsia — não será um prazer bem mais arrepiado, bem mais intenso do que o vago calafrio de beleza que nos pode proporcionar uma tela genial, um poema de bronze? [...] Assim, para todos, os prazeres dos sentidos são a luxúria, e se resumem em amplexos brutais, em beijos húmidos, em carícias repugnantes, viscosas. (28)

In her texture-laden discussion, she contrasts the beauty of a painting or poem in "bronze" with sensuality itself as an art. She takes sensuality to constitute more than the immaterial aspects of desire (êxtase, ânsia); rather, her conception includes the materiality of textures (brutal, húmido, viscoso). The American woman highlights the universal accessibility of sensual art but asserts that only a truly great artist could take sensuality as their raw material: "tinha o fogo, a luz, o ar, a água, e os sons, as cores, os aromas, os narcóticos e as sedas-tantos sensualismos novos ainda não explorados" (28). The woman, who we later 
discover is lesbian ("uma grande sáfica" (33)), links the senses to sensuality and illustrates this with textures, which to her are the greatest form of art when they are innately sensual. ${ }^{3}$

The American woman does not dispose entirely of visuality but grants the visual a new meaning in her own performance when she puts into practice the ideas she has previously expressed to Gervásio and Lúcio. Accompanied by Gervásio and his new acquaintance, Ricardo de Loureiro, Lúcio attends the party hosted by the woman, whose large salon suddenly changes upon their reentry for the show. Lúcio feels a colorful breeze passes through the room, prickling his skin; but the lighting is the truly spectacular feature, which he describes as "ondas," "torrentes," "um turbilhão," and the beams of light, which ricochet against one another, project back onto the walls, transforming the room (39). The light show demonstrates the power of the visual to influence perceptions of textural surfaces and, for Lúcio, this performance alters even the surface of his own skin. He thinks, "nós sentíamo-la [a luz] mais do que a víamos. E não receio avançar muito afirmando que ela não impressionava a nossa vista, mas sim o nosso tacto" (39). Lúcio goes on to describe the various physical ways that the lighting affected him, trading the superficial primacy of the visual for the privileging of the haptic as a truer way of experiencing the artistic, very modern performance.

Female dancers join the show, though gender and textures are as disconcerting here as with the lights, with legs molded "em aurora loura," "escalavradas de músculos, de durezas," the girls are appetizing or ice cold; their breasts, vulvas, everything move in an "arqueamento de vício" (41-42). The mixture of texture with markers of femininity and corporeality suggest the constructed, sculpted nature of bodies in motion. The American woman's appearance constitutes the crowning moment of the evening. Though naked, she represents more a work of art than an object of desire: her lips, nipples and vulva are painted gold, and her skin is adorned with jewels. ${ }^{4}$ Unveiling and veiling

\footnotetext{
${ }^{3}$ Among others, Curopos discusses the American woman and her potential relation to historical figures of the era: Loïe Fuller, Ida Rubenstein, etc. By using a lifelike character who is more sexually free, Curopos argues that Sá-Carneiro downplays the mythic nature of the Salomé figure while also adopting a "resolutely modern authorial position" (89). Curopos also discusses elements, such as the lighting, that contribute to a more modern (rather than mythical) reading.

${ }^{4}$ Jones's Butlerian analysis of the American woman's performance arrives at a similar conclusion regarding interest in the woman's body by the heterosexual male viewer; that is, the American
} 
herself once again, the American woman jumps into and possesses the flames around her, finally leaping into a pool of water, ostensibly dead. The eccentric follower of Sappho, early in A confissão de Lúcio, demonstrates the connection between the textural, the sensual, and art. She freely moves between and among these modes, breaking down differences not in a fragmented manner sometimes typical in modernity, but in a fluidity, that, while filled with seeming oppositions (flames and water), ignores resolution in favor of esthetic exposition.

In a sense, the American woman's ambiguous performance (in a both literal and Butlerian sense) challenges the conception of a binary gender system and in so doing also opposes the heterosexual imperative. Subversion also presents itself in her performance if we keep in mind Sherry's idea about reading modernism backward: "beyond reading the fin de siècle forward, we learn to read modernism backward [...] into the sensibility of decadence and, among other things, into those backward orientations manifested most apparently (but not only) in queer temporalities" (27). This is the case when the American woman leaps into the pool, fire and water touch, and only gilded water and the woman's body remains. Her performance distills into art a subversion of the modern that it represents by coming forward into existence and disappearing into apparent death. The language of texture describes the show in visceral terms that befuddle notions of gender in a way that also challenges the idea of a fixed binary. Lúcio, along with Ricardo, see the American woman's "death" and she herself as mysterious, "de Além” (46), a decadent notion present in much of Sá-Carneiro's prose, but Lúcio will remember the night not only because of the captivating performance, but because that is when he became friends with Ricardo de Loureiro. ${ }^{5}$

woman espouses "a version of femininity that so exceeds dominant demarcations of 'the feminine' that it is itself incompatible with female-coded anatomy" (67).

${ }^{5}$ The theme of Mystery or Beyond (always in capital letters) is present, for example, in SáCarneiro's collection Céu em fogo (1915). In those stories, we are introduced to narrators who witness strange and impossible events of artists, scientists, or others who somehow disappear in gaining entry to the Mystery or Beyond. The titles of the stories themselves emphasize these themes: "A grande sombra," "Mistério," "O homem dos sonhos," "Asas," "Eu-próprio o outro," "A estranha morte do Prof. Antena," "O fixador de instantes," and "Ressurreição." Eiras, referring to Sá-Carneiro's prose generally, states that the author's alienation "takes place through the invention or discovery of an ideal being [...] the subject meets an Other, an artist, who is beautiful, exotic and enigmatic" (306). Sapega notes that the novellas represent "o desenvolvimento, até aos seus limites metafóricos, dos perigos evidentes no projeto estético seguido por Mário de SáCarneiro" (75). 


\section{Pressing Deeper: Ricardo}

Upon meeting Ricardo, Lúcio's relationship with Gervásio quickly fades to the background. Lúcio feels an immediate draw to the man whose appearance he describes in contrasts of radiance and shadows and in the vocabulary of lighting and mirrors. Lúcio's word choice reflects the play of appearances that serves as the cornerstone of his imagining of modernity. His friend's eyes "não brilhavam: cobriam-se de um véu de luz" (57), and just as Lúcio feels he approaches a glimpse of Ricardo's inner-workings, he finds he never manages to "descer uma psicologia" (57). Ricardo's impenetrability contrasts with his self-declared openness, which intrigues Lúcio and draws him close enough to assert, "compreendiam-se perfeitamente as nossas almas" (58). Eventually, the topic of love and sex arises and Ricardo expresses his "ânsia sexual de possuir vozes, gestos, sorrisos, aromas e cores!” (65). A fear of losing himself follows Ricardo's affirmation and though he suggests that Lúcio write about it, Ricardo's line of thought captures the tension of an artist caught between wanting to possess the essence of modernity - represented by the myriad sensations - and his fear of losing himself in that process.

To possess always carries a gendered meaning in A confissão de Lúcio and it seems to contradict the typical masculinist assumption of male possessor and female object of possession in a hegemonic heterosexist understanding of sexual relations. Ricardo asserts that if he were a woman, he would never let himself be possessed "pela carne dos homens - tristonha, seca, amarela: sem brilho e sem luz" (69). He continues in the same vein:

Sou todo admiração, todo ternura, pelas grandes debochadas que só emaranham os corpos de mármore com outros iguais aos seusfemininos também. [...] E lembra-me então um desejo perdido de ser mulher [para que] pudesse olhar as minhas pernas nuas, muito brancas, a escoarem-se, frias, sob um lençol de linho. (69)

In this imagined scenario, Ricardo's gender bending is directly tied to textures as well to a certain ambiguity about whether he would become a woman entirely or assume the shape of one. For Ricardo, the capacity for touch (and therefore texture and texxture) is permissible only in a female form. His word choice 
Pechstein

evokes both the visuality and physicality of materials such as marble, skin, and linen. In the imagined slippery, bare coolness, Ricardo figures a paradise of desirable tactility that recalls the American woman's sensuality and sexuality. In Ricardo's statement, we find more than the simple conditional "if I were a woman," but a gazing upon himself (herself?) as a woman and the fantasy of physical contact with another woman. This desire to transform is later repeated, queered in his discussion with Lúcio.

Queerness, texturality, and possession converge more fully when Ricardo expresses his desire to draw closer to Lúcio and the problem presented by that desire. He frames the issue in the following manner: "eu não sou seu amigo. Nunca soube ter afetos [...] apenas ternura. A amizade máxima, para mim, traduzir-se-ia unicamente pela maior ternura. E uma ternura traz sempre consigo um desejo caricioso: um desejo de beijar [...] de estreitar [...] Enfim: de possuir!" (71). With his declaration, Ricardo lays out the impossible terms of his relationship with Lúcio and embeds those in the language of tactility: "ternura," "caricioso," "beijar," and "possuir." Ricardo's words link texture and texxture to a queerness that is evoked by the intimacy of the vocabulary chosen and by the male interlocutor. At the same time, the apparent necessity to shift genders to avoid a homosocial possession reinforces the masculinist heterosexual imperative because it negates the very possibility of possessing someone of the same gender. Queerness in relation to both gender and sexuality continues as the theme of the conversation when Ricardo echoes his formerly stated desire to experience himself as a woman, declaring: "para ser amigo de alguém (visto que em mim a ternura equivale à amizade) forçoso me seria antes possuir quem eu estimasse, ou mulher ou homem. Mas uma criatura do nosso sexo, não a podemos possuir. Logo eu só poderia ser amigo de uma criatura do meu sexo, se essa criatura ou eu mudássemos de sexo" (71). Ricardo relates tenderness to possession and tenderness itself exists as an emotional feeling as well as an element of texture (the tenderness of flesh, for example). If Ricardo can possess (penetrate the tender flesh of) Lúcio, then the two can truly be friends. By establishing such terms, Ricardo at once dooms the possibility of achieving a deep relationship with Lúcio and hints at a potential queer solution. In a sense, Ricardo suggests gender fluidity as the solution: by dissociating himself from his sex and its socially informed hegemonic masculinist rules, he is free to imagine possessing his friend, which is linked by tenderness to homosexuality as well as 
to a texture that he understands as different from the visuality of the surface. Ricardo's thoughts echo the earlier exploration of sensuality and textures by the American woman, whose female body became art, but possessed only the flames about her rather than another person.

In a sense, Ricardo is A confissão de Lúcio's artist who represents or exists in a "Beyond." Lúcio finds himself attracted to Ricardo's enigmatic nature that appears to reveal itself clearly just like the facts of modern life that Lúcio sees around him: cosmopolitan Paris, artistic circles, late nights at the cafés, lights, metallic surfaces, visual spectacles etc. All these Lúcio perceives through his optic senses, but they cannot be grasped tangibly and as such cannot be owned or possessed. Ricardo's declarations reflect the alienation associated with modernity that Calinescu describes as a common theme in decadent esthetics (162). He embodies Lúcio's vision of modernity and at the same time points to certain reservations, for Sá-Carneiro's modernity is one that reaches out to touch and desires to possess. In the modern world portrayed in A confissão de Lúcio, shapes shift, the senses overwhelm, and solidified concepts of gender and relationships no longer exist. To position Ricardo as requiring physical possession to culminate a friendship, but to negate that very possibility as gendered or even sexualized, constitutes a representational failure insofar as $A$ confissão de Lúcio refuses to allow the terms it lays out to come to fruitionwhat Sherry, drawing upon Lee Edelman and Heather Love, might call a denial of futurity. Lúcio never reaches the Beyond, he will never be Ricardo's friend on Ricardo's terms in part because of the strict gender dynamics that cannot be completely overcome.

\section{Tex(x)tures: Marta}

After Ricardo goes back to Portugal, Lúcio also returns to his country of birth and finds Ricardo in Lisbon. Lúcio notes that his friend's "feições bruscas haviam-se amenizado, acetinado" (76), terms Lúcio recognizes as associated with femininity. Connected to this, Lúcio believes that Ricardo's newfound womanliness is directly related to his recent marriage to Marta, whom Lúcio refers to as: "uma linda mulher loira, muito loira, alta, escultural — e a carne mordorada, dura, fugitiva. $O$ seu olhar azul perdia-se de infinito, nostalgicamente. [...] Um rosto formosíssimo, de uma beleza vigorosa, talhado 
em oiro. Mãos inquietantes de esguias e pálidas" (7). Lúcio describes Marta as firm and statuesque and, at the same time, claims that her flesh is fugitive. Her face is said to be carved out of gold, a precious metal that is both malleable and brilliant. At the textural level, Marta takes on many characteristics that approximate her to Ricardo himself, an observation that is strengthened by Ricardo's previous comments about becoming a woman to be able to possess his friend. Lúcio sees Marta as being carved (as if she was a statue) and, with this, he implicitly understands that Ricardo is her sculptor - indicating that the artist can shape not only works of art but gender itself. The malleability that the American woman represented in the first pages returns here and achieves a greater depth insofar as the relations between Lúcio, Ricardo, and Marta constitute the primary drive of the novella's plot.

Further contributing to the idea that Ricardo and Marta are the same, Lúcio states that Marta's "maneira de pensar nunca divergia da do poeta [Ricardo]" (79). Marta's opinions being in-line with Ricardo's is only one example of many that lead the reader to believe that the two are in fact the same. Lúcio also compares Marta's femininity to that of Serge Warginsky (another member of Ricardo's group of friends): "se alguma mulher havia entre nós, parecia-me mais ser ele do que Marta" (80). Lúcio's comment masculinizes the presumably female Marta when he describes Serge (an ostensibly male character) as the one true feminine presence in the room. Marta's masculinity, or her gender-bending in general, mirrors Ricardo's own previously mentioned desire to change gender. In this way, Ricardo and Marta approximate one another not only in Lúcio's direct observations, but also in their embodiment of gender fluidity - whether that be perceived or real. These moments of gender confusion or direct gender bending demonstrate A confissão de Lúcio's doubt in relation to the relative importance of gender distinctions among the group of artists and their friends. Paradoxically, gender itself as well as a certain compulsory heterosexuality are paramount to the conception of possession in the novella and the ability to achieve true friendship between its characters. ${ }^{6}$

For Lúcio, Marta - even more so than Ricardo - can be understood to represent the impossible nature of or the failure to truly grasp modernity. Lúcio

\footnotetext{
${ }^{6}$ For an argument against the view that heterosexuality is innate and that women are somehow inevitably drawn toward men, see Rich.
} 
questions Marta's "immediate" nature for "essa mulher não tinha recordações; essa mulher nunca se referira a uma saudade da sua vida [...] como se não tivesse um passado-como se tivesse apenas um presente!” (84). Lúcio's preoccupation with Marta's past echoes the primacy of mythologized pasts and the interest in the future that are both common in modernity. ${ }^{7}$ The intangibility of past and the denial of future frustrates Lúcio for when he presses Marta for answers about her history, he finds that social delicacies prevent him from exploring her mysteriousness, stating: "perturbava-me como se viesse de cometer uma indelicadeza" (85). The attention to arbitrary rules reminds us of the earlier moment when Ricardo established standards for the depth of his friendships. The social norms that dictate his everyday interactions prevent Lúcio from pressing into the surface of Marta's presentness/presence and once again highlight a certain denial of futurity that Sherry associates with decadence. While social delicacies were suspended in the American woman's performance, they initially entice and impede Lúcio's interest in Marta. Soon, the lines between the plausible and untenable disintegrate (as decadent esthetics tend to do) when Lúcio, at a play with Marta (aptly titled Além), believes that he sees her "dissipar-se, esbaterse, som a som, lentamente, até que desapareceu por completo" (87). Lúcio obsesses not only over Marta's past, but also over the tangibility of her physical being, wishing to be the one to possess her where possession is associated with physicality and textures.

When Marta clasps Lúcio's hand, however, Lúcio admits to himself that it was not he who possessed her, rather, it was she who possessed him. As the two continue their affair, Lúcio begins to associate their encounters with "incompreensíveis náuseas [...] um além-gosto a doença, a monstruosidade, como se possuíra uma criança, um ser de outra espécie ou um cadáver" and yet he still finds her body "um triunfo; o seu corpo glorioso [...] o seu corpo bêbado de carne - aromático e lustral, evidente [...] salutar" (105). Lúcio's view of being with Marta as simultaneously nauseating and triumphant reflects his conflicted feelings regarding his actions toward her, and against his friend and her husband,

\footnotetext{
${ }^{7}$ Peter Childs notes that, for some thinkers, modernity is "the culmination of the past and the harbinger of the future" (15-16). He further comments on the idea that modernist texts often "subsume history under mythology and symbolism" (19). Childs and other critics also mention Walter Benjamin's Angel of History, which faces the past while being propelled into the future. In A confissão de Lúcio, Marta's existence in the present might cause anxiety because it denies any past—invented or not—and her unpredictability blinds Lúcio to their potential future together.
} 
Ricardo. The paradox that she both causes sickness or perversity and at the same time provides purification and health repeats Lúcio's apprehension about the modern world he lives in and the modern friendships he at once values and fears. Since Gervásio, Lúcio has searched for more depth in his relationships, and he believes that he can achieve this with Marta. Nevertheless, such can only occur if Lúcio overcomes his awkwardness, draws nearer to perversion, and challenges the liminal borders of the flesh. Furthermore, this attitude shows a willingness (or even desire) to avoid the question of futurity, which would be replaced by the physicality of possession.

To reach further in their relationship, Lúcio duplicates Ricardo's strategy of possession - acceptable in the form of an affair - to attempt a deeper connection with Marta. However, he once again struggles with Marta's nearly immaterial nature, lamenting, "coisa alguma me restava que, materialmente, me pudesse provar a sua existência” (108). When he attempts to recall her features, Ricardo's come to mind. The slippage that occurs between Marta and Ricardo comes to an especially dramatic moment when Ricardo himself kisses Lúcio, described by the latter here: "o beijo de Ricardo fora igual, exactamente igual, tivera a mesma cor, a mesma perturbação que os beijos da minha amante. Eu sentira-o da mesma maneira" (113). Not only are Marta and Ricardo alike in their opinions and certain surface textures, but the depth of their touch (texxture) also feels the same. In A confissão de Lúcio, possession subsumes all other preoccupations; it remains in the realm of the physical: in the slipperiness of the surface or, as we will now see, in the "give" of skin. To the characters, it would appear that texture is more truthful than words or vision.

Lúcio, suspecting that he is not Marta's only lover, imagines that, in their lovemaking, he possessed "todos os corpos masculinos que resvalavam pelo seu"-his obsession becomes "achar na sua carne uma mordedura, uma escoriação de amor, qualquer rastro de outro amante" (123-24). Leaving the homoerotic charge of such a statement aside, Lúcio has evidently accepted, indeed he is shown to perpetuate Ricardo's insistence on touch and possession as the only legitimate ways to experience the depth of a relationship. Lúcio's phrasing echoes the queerness tied to the idea put forth by Ricardo when the object of possession is no longer solely his lover, but all the male bodies that he imagines she has possessed. The repercussions of Lúcio's view take on greater proportions with the narrative's insistent suggestion that Marta and Ricardo 
belong to the same being as that would mean that he is driven to mark Ricardo and partake of his lovers. When Lúcio finds a bruise on Marta's left breast, he glues his "boca a essa mancha-chupando-a, trincando-a, dilacerando-a" (124). Marta remains silent even when Lúcio tastes blood. The drive to bite or otherwise make an imprint on the texture and texxture of the skin of his lover reflects Lúcio's desperation to claim Marta. To mark his territory haptically lends a physical credibility to the otherwise intangible nature of their relationship. At the same time, Lúcio attempts to unite the past of a bruise, the present of his teeth on her skin, and the future represented by the mark he will leave. While Lúcio imagines that he is possessing her other lovers-which might be said to establish her as a proxy - I question whether this line of thought is possible when Lúcio at the same time considers Ricardo and Marta as one. Can Lúcio's affair with Marta truly be a proxy for a deeper, more tactile friendship with Ricardo if Marta and Ricardo are the same? Questioning the idea of a triangular relationship and the notion of Marta as proxy presents a challenge to readings of A confissão de Lúcio that derive from Sedgewick's notion of homosocial desire that requires a woman to negotiate relations between men.

After a brief stay in Paris to clear his mind, Lúcio returns to Lisbon to confront Ricardo, who, he discovers, always knew about his friend's affair with Marta. Ricardo laments that he could never feel affection or satisfy his feelings of tenderness, to make his friendships whole. He says to Lúcio: "só se te beijasse, se te enlaçasse, se te possuísse" (154) could he truly reciprocate his friendship. Ricardo repeats his feelings about friendship and possession, stressing the importance of touch and texxture, for he claims, "eu vi a tua amizade, nitidamente a via, e não a lograva sentir! Era toda de ouro falso" (154). Ricardo focuses on the distinction between the visual and the tactile, employing the pyrite simile to underscore the duplicitous nature of Lúcio's friendship. Referring to Marta, Ricardo further explains:

Achei-A [...] sim, criei-A! criei-A [...] Ela é só minha—entendes?-é só minha! [...] Compreendemo-nos tanto, que Marta é como se fora a minha própria alma. Pensamos da mesma maneira; igualmente sentimos. Somos nós-dois [...] Desde essa noite eu soube, em glória soube, vibrar dentro de mim o teu afecto-retribui-to: mandei-A ser tua! Mas, estreitando-te ela, era eu próprio quem te estreitava [...] E só com o 
Pechstein

espírito te possuí, materialmente! Eis o meu triunfo [...] Triunfo inigualável! Grandioso segredo! (154)

Here it appears Ricardo and Marta have or always were merged. This passage is one of A confissão de Lúcio's culminating moments and counts among its most lucid attempts at resolving the problem that the narrative itself created: Ricardo originally claimed that he could be true friends with Lúcio only if he were to possess him and furthermore stated that he could do no possessing unless he were of a different sex. When Ricardo reveals that he created Marta and that she is a part of himself, he points to what would be the solution to the dilemma. However, when Sá-Carneiro positions the answer to Ricardo's problem of possession as a "grandioso segredo," he obfuscates the process of arriving at the solution or any future repetition.

Soon thereafter, Ricardo's behavior becomes erratic, and he takes Lúcio to find Marta. Lúcio feels "disperso de alma e corpo" as Ricardo shouts "foi como se a minha alma, sendo sexualizada, se materializasse para te possuir" (156). While Lúcio's body is said to dissolve, Ricardo claims that his soul had become flesh in the form of Marta. Each statement points to the amorphous nature of the body and soul, which, in turn, recalls corporeal fluidity especially in relation to gender. Lúcio is caught up in the madness and recognizes that Ricardo's words are incoherent and impossible. Ricardo pushes open the door to reveal Marta, he pulls out his revolver, and shoots Marta point-blank. Lúcio writes of the moment: "e então foi o Mistério [...] o fantástico Mistério da minha vida" continuing, "quem jazia estiraçado junto da janela, não era Marta—não!—, era o meu amigo, era Ricardo [...] E aos meus pés—sim, aos meus pés! — caíra o seu revolver ainda fumegante!" (157). Lúcio finishes his thoughts by stating, "Marta, essa desaparecera, evolara-se em silêncio, como se extingue uma chama" (157). Here it is Marta who disappears, completing, in a way, the act that the American woman began when she leapt into her own flames. Should the reader consider Ricardo and Marta's existence(s) as figurative representations of the trajectory of modernity, the results are gruesome. In a novella where the queerness of multilayered tactility plays an important role in relation to possession, the culminating moment shows that even under the proper circumstances (with Marta as the link), the homosocial bond between Ricardo and Lúcio can never be successfully consummated. However, if we understand (as the characters do) that 
Ricardo and Marta are one and the same, then the queerness of their mutual possession becomes more complex than a love triangle or relationship by proxy. ${ }^{8}$

\section{Conclusion}

Textures and sexuality invest heavily in liminality and carry sensual connotations that can evoke gendered and queer readings. Gervásio Vila-Nova, as brilliant as he was, constituted a prime example of an artist interested only in exteriors and appearances - he did not offer the deeper level of friendship that Lúcio craved. That said, Gervásio presented Lúcio to the American woman, who introduced the narrator-protagonist to the concept of sensuality in art and extended the potential of surfaces and light to a tex(x)tural plane. At her performance, Lúcio meets Ricardo de Loureiro, the enigmatic man who Lúcio admires, and, in relation to their potentially deeper friendship, fears. Throughout, Lúcio grapples with connecting to art and to artists themselves in his modern milieu. Possession, as framed by Ricardo, becomes the solution to achieving a deeper relationship with his artist friend, but, as a solution, it remains unattainable because of social gender rules tied to hegemonic masculinity. Ricardo's possession is linked inextricably to textures and it is through tactility that Lúcio draws closer to Marta, who is one with Ricardo. Unfortunately, the final scene extinguishes Ricardo and Marta before Lúcio can explore, truly feel, the deeper connection with Ricardo. Thus, the novella can be described as a magnificent esthetic project. A confissão de Lúcio cannot, however, be said to resolve the issue of Lúcio's relationship to modernity nor the crisis of artistic representation and relations that he faces. Rather, the narrative puts forth ideas about sensuality and art, textures and queering, presenting gender ambiguity and the primacy of possession as ends sufficiently interesting in and of themselves.

I understand the concept of possession to be the privileged means of bridging the gap between A confissão de Lúcio's modern subjects. Through the lens of queer tactility, tex(x)tures become useful in understanding possession itself as well as the convergence of Ricardo and Marta. Ultimately, there is no answer to what the end of the story means, and perhaps that is precisely the point. The novella, through the positioning of its characters as dependent on an unattainable,

\footnotetext{
${ }^{8}$ For a more detailed analysis of the love triangle/proxy hypothesis, see Arenas.
} 
un-embodiable connection, present a fraught, decadent approach to modernitynot a logical system. It is an approach that recognizes the fragile nature of the singular self in relation to others. Indeed, Sá-Carneiro's response to modernity ultimately rejects the unfolding of the self into multiple selves or any other possessable solution and instead valorizes ambiguity and esthetics.

\section{Works Cited}

Arenas, Fernando. "Onde existir? A (im)possibilidade excessiva do desejo homoerótico na ficção de Mário de Sá-Carneiro.” Metamorfoses, vol. 6, 2005, pp. 159-68.

Beleza, Fernando. "Peripheral Desires, Modernist Fantasies: Mário de SáCarneiro's Queer Cosmopolitanism." Mário de Sá-Carneiro, A Cosmopolitan Modernist, edited by Fernando Beleza and Simon Park. Peter Lang, 2017, pp. 113-36.

-. "Pessoa and the Death Drive: Decadence, Heteronomy, and the Making of Modernism." Academia.edu, 2016, www.academia.edu/29300914/Pessoa _and_the_Death_Drive_Decadence_Heteronomy_and_the_Making_of_ Modernism.

Bora, Renu. "Outing Texture." Novel Gazing: Queer Readings in Fiction, edited by Eve Kosofsky Sedgwick, Duke UP, 1997, pp. 94-127.

Butler, Judith. Gender Trouble: Feminism and the Subversion of Identity. Routledge, 1990.

Calinescu, Matei. "The Idea of Decadence." Five Faces of Modernity, Duke UP, 1987, pp. 149-224.

Childs, Peter. "Introduction." Modernism, 3rd ed., Routledge, 2017, pp. 1-35.

Curopos, Fernando. "Mário de Sá-Carneiro and the Demons of Dance." Mário de Sá-Carneiro, A Cosmopolitan Modernist, edited by Fernando Beleza and Simon Park, Peter Lang, 2017, pp. 69-112.

Eiras, Pedro. "A Scattering of Shards: The Fragmentation of the Subject in the Orpheu Generation." Portuguese Modernisms: Multiple Perspectives on Literature and the Visual Arts, edited by Steffan Dix and Jerónimo Pizarro, Legenda, 2011, pp. 294-309. 
Ginway, Mary Elizabeth. "Transgendering in Luso-Braziliain Speculative Fiction from Machado de Assis to the Present." Luso-Brazilian Review, vol. 47, no. 1, 2010, pp. 40-60.

Jones, Eleanor K. "Undone Anatomies: Femininity, Performativity and Parody in Mário de Sá-Carneiro's A Confissão de Lúcio.” Portuguese Studies, vol. 32, no. 1, 2016, pp. 62-71.

Rich, Adrienne. "Compulsory Heterosexuality and Lesbian Existence." Signs, vol. 5, no. 4, 1980, pp. 631-60.

Rita Lopes, Teresa. "Pessoa, Sá-Carneiro e as três dimensões do Sensacionismo." Colóquio Letras, vol. 4, 1971, pp. 27-35.

Sá-Carneiro, Mário de. Céu em fogo. Ática, 1956.

—. A confissão de Lúcio. 8th ed. Ática, 1995.

Sapega, Ellen W. "Em busca da velada súbtil: experiência, marginalização e ruptura nas novelas de Céu em fogo.” Colóquio: Letras, no. 117-18, 1990, pp. 103-19.

Sherry, Vincent. Modernism and the Reinvention of Decadence. Cambridge UP, 2015. 